\title{
Expression of a Constitutive NF- $\kappa$ B-like Activity is Essential for Proliferation of Cultured Bovine Vascular Smooth Muscle Cells
}

Robert E. Bellas, John S. Lee, and Gail E. Sonenshein

Department of Biochemistry, Boston University School of Medicine, Boston, Massachusetts 02118

\begin{abstract}
We have recently discovered bovine and human vascular smooth muscle cells (SMCs) express a novel constitutive

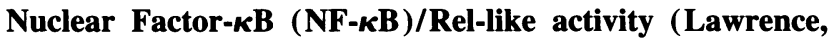
R., L.-J. Chang, U. Siebenlist, P. Bressler, and G. E. Sonenshein. 1994. J. Biol. Chem. 269:28913-28918), here termed SMC-Rel. Since cytomegalovirus (CMV) infection of human vascular SMCs has been implicated in aberrant SMC proliferation during post-angioplasty restenosis, we tested the role of $\mathrm{NF}-\kappa \mathrm{B} /$ Rel activity in transactivation of the CMV immediate early (ie) promoter. The basal CMV ie promoter linked to three wild-type, but not mutant, copies of its NF- $\mathrm{B}$ element was active in bovine aortic SMCs. The anti-oxidants $\mathrm{N}$-acetyl cysteine (NAC) or pentoxifylline (PTX), which are used clinically to reduce NF- $\mathrm{KB} / \mathrm{Rel}$ activity, inhibited NF- $\kappa$ B driven promoter transactivation, and SMC-Rel binding activity. Treatment with either NAC or PTX was observed to slow the growth of the SMCs in a dose dependent fashion. Microinjection of either purified IKB- $\alpha$, a naturally occurring specific inhibitor of NF- $\mathrm{KB} / \mathrm{Rel}$ activity, or double-stranded oligonucleotides harboring wild type, but not non-binding mutants of NF- $\mathrm{B}$ elements selectively inhibited SMC proliferation. Thus constitutive NF$\kappa B / R e l$ activity appears essential for proliferation of vascular SMCs and might be a novel target for therapeutic intervention for restenosis. (J. Clin. Invest. 1995. 96:2521-2527.) Key words: SMC-Rel $\cdot$ CMV $\bullet \boldsymbol{N}$-acetyl cysteine $\bullet$ pentoxifylline $\cdot$ restenosis

\section{Introduction}

Members of the NF- $\kappa B^{1} /$ Rel family of transcription factors play important roles in the regulation of transcription of a variety of

Address correspondence to Dr. Gail E. Sonenshein, Department of Biochemistry, Boston University Medical School, 80 East Concord Street, Boston, MA 02118. Phone: 617-638-4120; FAX: 617-638-5339; E-mail: gsonensh@med-biochm.bu.edu

Received for publication 3 April 1995 and accepted in revised form 7 August 1995.

1. Abbreviations used in this paper: $\beta$-gal, $\beta$-galactosidase; CAT, chloramphenicol acetyl transferase; CMV, cytomegalovirus; $i e$, immediate early gene of CMV; I $\kappa$ B- $\alpha$, NF- $\kappa$ B inhibitor- $\alpha$; NAC, $N$-acetyl cysteine; NF- $\kappa$ B, Nuclear Factor $-\kappa B$; PTX, pentoxifylline; SMC, smooth muscle cell; SMC-Rel; novel constitutive Rel-like subunit expressed in SMCs.

J. Clin. Invest.

(C) The American Society for Clinical Investigation, Inc. 0021-9738/95/11/2521/07 \$2.00

Volume 96, November 1995, 2521-2527 cellular and viral genes, including the c-myc oncogene $(1,2)$, several interleukins, receptors and adhesion molecules, and genes of the HIV-1 (for reviews see references 3 and 4) and cytomegalovirus (CMV) $(5,6)$. NF- $\kappa \mathrm{B}$ activity can be induced in a wide variety of cell types in response to treatment with such agents as IL-1, TNF $\alpha$, adhesion, oxidative stress, and oxidized LDL $(3,4)$. The inducible $N F-\kappa B / R e l$ activity is due to release of sequestered cytoplasmic NF- $\kappa \mathrm{B}$ from inhibitor $\mathrm{I} \kappa \mathrm{B}$ proteins $(7,8)$. In this manner, NF- $\kappa \mathrm{B} / \mathrm{Rel}$ family members can serve as important second messengers in signal transduction. Constitutive nuclear NF- $\kappa \mathrm{B}$ activity appeared to occur only in mature B cells, activated $\mathrm{T}$ cells and monocytes, and neurons, but we recently demonstrated bovine and human vascular SMCs express an NF- $\kappa \mathrm{B}-$ like activity constitutively (9). This factor activated transcription of a heterologous promoter driven by mutimerized elements of the immunoglobulin kappa light chain or the c-myc gene, as well as the HIV long terminal repeat. Despite extensive efforts to identify this activity as one of the previously identified Rel-family members, we have been unable to do so, raising the possibility that this factor is a novel SMCspecific member of the NF- $\kappa \mathrm{B} / \mathrm{Rel}$ family (now termed SMC-Rel).

Vascular smooth muscle cells are a major constituent of the medial layer of blood vessels and have been implicated in the development of atherosclerotic plaques (10). Aberrant proliferation within the intima following injury leads to excessive production of extracellular matrix and contributes to the occlusion of the arteries. In addition, in $25-50 \%$ of patients receiving coronary angioplasty, a process called restenosis involving significant SMC proliferation occurs which often leads to reclosure of the vessel (10). An understanding of the mechanisms by which SMC growth is regulated is crucial to the development of effective treatments for these disorders. In light of a recent report demonstrating that aberrant SMC proliferation in postangioplasty restenosis may be a result of CMV infection and consequent stabilization of the tumor suppressor p53 (11), we sought to determine whether constitutive SMC NF- $\kappa \mathrm{B} / \mathrm{Rel}$ factors might play a role in the activation of the CMV immediate early (ie) gene promoter through its NF- $\kappa \mathrm{B}$ sites. Using transient transfection, here we report that the NF- $\kappa \mathrm{B}$ elements play a significant role in constitutive activation of the CMV ie gene promoter in bovine aortic SMCs. Addition of anti-oxidants, that have been found to inhibit NF- $\kappa \mathrm{B} / \mathrm{Rel}$ activity (4), caused a decrease in transactivation of CMV promoter and NF- $\kappa \mathrm{B}$ element driven constructs that could be related to a decline in SMC-Rel binding. Furthermore, it was noted that these inhibitors slowed SMC growth, and microinjection experiments indicated an essential role for $\mathrm{NF}-\kappa \mathrm{B} / \mathrm{Rel}$ in proliferation of SMCs in culture. 


\section{Methods}

Cell culture. Vascular SMCs were obtained by explant of bovine aorta as previously described (9) and grown in Dulbecco-Vogt minimal essential medium (DMEM) supplemented with $4 \mathrm{mM}$ glutamine, $50 \mathrm{U} / \mathrm{ml}$ penicillin, $50 \mu \mathrm{g} / \mathrm{ml}$ streptomycin and $10 \%$ fetal bovine serum (GIBCO Laboratories, Grand Island, NY). These cells, which have a synthetic phenotype and express only very low levels of SMC actin, were used within the fourth passage. Bovine aorta endothelial cells, kindly provided by $\mathrm{D}$. Larson, were similarly cultured. SMCs were rendered quiescent by growth to confluence as described (9). Interleukin-1 (IL-1) and interleukin 6 (IL-6) (kindly provided by J. Sipe) were added to $10 \mathrm{ng} /$ $\mathrm{ml}$ for $1 \mathrm{~h}$ before preparation of nuclear extracts. $\mathrm{N}$-acetyl cysteine (NAC) (Sigma Chemical Co., St. Louis, MO) was prepared as a 200 $\mathrm{mM}$ stock in DMEM and adjusted to pH 7.3 with $1 \mathrm{~N} \mathrm{NaOH}$ immediately before addition to cells. Pentoxifylline (PTX) (Sigma) was prepared as a $100 \mathrm{mM}$ stock in DMEM.

Transfection and reporter gene assays. For the CMV constructs, cells were transfected by the modification of the calcium phosphate method described by Chen and Okiyama (12). CMV Lac Z reporter gene constructs, kindly provided by E. Mocarski, were the following: pON405, 2000 bp of sequences upstream of the murine CMV ie 1 transcription start site, including five full and six partial $18 \mathrm{bp} \mathrm{NF}-\kappa \mathrm{B}$ element repeats; pON407, a deletion of sequences up to $-146 \mathrm{bp}$ of the CMV ie1 transcription start in pON405, including all of the NF- $\kappa \mathrm{B}$ elements; pON407.18R3, insertion of three tandem copies of the wild type NF- $\kappa$ B element 18R3 (CCTTAACGGGACTTTCCAA) just upstream of $-146 \mathrm{bp}$ of the pON407; pON407.18(TTT)R3, insertion of three tandem copies of a mutated version of the NF- $\kappa$ B element termed $18 T 3$ (CCTTAACTTTACTTTTCCAA) just upstream of $-146 \mathrm{bp}$ of the pON407 $(5,6) .24 \mathrm{~h}$ before transfection, $5 \times 10^{5}$ cells were plated in duplicate in P100 dishes. Cells were transfected with $10 \mu \mathrm{g}$ reporter construct, $2.5 \mu \mathrm{g}$ MoECAT, a chloramphenicol acetyl transferase (CAT) reporter gene under the control of the Moloney Murine Leukemia Virus long terminal repeat, for normalization of transfection efficiency and $17.5 \mu \mathrm{g} \mathrm{BS}(+)$ or pUC19 carrier DNA to have a final total amount of $30 \mu \mathrm{g}$ DNA, which is optimal for transfection of SMCs under these conditions. CAT assays were performed on protein extracts using a continuous fluor diffusion assay (13), as we have described previously (9). Extracts, normalized for transfection efficiency, were subsequently assayed for $\beta$-galactosidase activity (14). In addition, constructs containing two copies of wild type or mutated versions of the NF- $\kappa$ B element (URE from upstream of the c-myc promoter) linked to the thymidine kinase (TK) promoter driving the CAT plasmid, described previously (9), were used. For transfection of these constructs, SMCs were grown to confluence, trypsinized, resuspended in medium plus $20 \%$ serum at a concentration of $20 \times 10^{6}$ cells per ml. A sample $(0.8 \mathrm{ml})$ of cell suspension was incubated on ice for 5 minutes, then electroporated with $30 \mu \mathrm{g}$ DNA at $300 \mathrm{~V}$ and $960 \mu \mathrm{F}$ using a Gene Pulser (Bio-Rad Laboratories, Richmond, CA), then returned to ice for $10 \mathrm{~min}$. Cells were then plated at a density of $10^{4}$ cells per $\mathrm{cm}^{2}$. After $24 \mathrm{~h}$, cells were harvested, and protein concentration of the lysates determined using a Bio-Rad kit, according to the manufacturer's directions. Equal amounts of protein were assayed for CAT activity.

Oligonucleotide sequences. URE double-stranded oligonucleotide containing the upstream NF- $\kappa$ B element of the murine c-myc gene (1) was used in either wild type or mutant forms as follows:

URE: GATCCAAGTCCGGGTTTTCCCCAACC

mURE1: GATCCAAGTCC $\overline{G C C T T T T C C C C A A C C}$

mURE2: GATCCAAGTCCGGGTTCCCCCCAACC

mURE3: GATCCAAGTCCGGGTTTTGGCCAACC

mURE4: GATCCAATGAAGGGTTTTCCCCAACC.

The region critical for binding, indicated by methylation interference (1) and mobility shift analysis (9), is underlined in the wild-type URE sequence. The mutations, indicated in bold font, are in the binding region in mutants 1,2 , and 3 and outside of the core binding region in mutant 4 . The oligonucleotide containing the NF- $\kappa$ B element from the kappa light chain gene was CAGAGGGGACTTTCCGAGAGG (3).
For AP-1 binding, the double stranded oligonucleotide (with binding site underlined) used was: GATCGCCATGTGACTCATTAC.

Electrophoretic mobility shift assay. Nuclear extracts were prepared by a "miniprep" procedure described previously (15), and quantitated for protein, as above. Oligonucleotides were ${ }^{32} \mathrm{P}$-labeled to an approximate specific activity of $6000 \mathrm{Ci} / \mathrm{mmol}$ and purified by polyacrylamide electrophoresis. Nuclear extract ( $5 \mu \mathrm{g}$ ) was mixed with $10 \mu \mathrm{g}$ poly (dIdC) (Pharmacia, Piscataway, NJ) and 25,000 dpm of labelled doublestranded oligonucleotide in $2 \mathrm{mM}$ Hepes $\mathrm{pH} 7.5,1 \mathrm{mM}$ dithiothreitol, $0.1 \%$ Triton X-100, $0.5 \%$ glycerol, and $100 \mathrm{mM} \mathrm{KCl}$ in a volume of $25 \mu \mathrm{l}$ and incubated at $23^{\circ} \mathrm{C}$ for $30 \mathrm{~min}$. DNA-protein complexes were resolved by nondenaturing polyacrylamide electrophoresis in $4.5 \%$ acrylamide, employing as buffer $0.022 \mathrm{M}$ Tris-borate, $0.5 \mathrm{mM}$ EDTA (9)

Determination of the number of cells in $S$ phase. The number of cells traversing S-phase in a defined time period was determined by incubating cells in media containing $\left[{ }^{3} \mathrm{H}\right]$ thymidine (New England Nuclear) at $2 \mu \mathrm{Ci} / \mathrm{ml}$ for the indicated time periods. At the end of the labeling period, cultures were washed five times in phosphate buffered saline, fixed with $-20^{\circ}$ methanol for five minutes, and air dried. Cells were overlayed with NTB2 emulsion (Eastman Kodak Co.) and exposed in the dark for five days. The emulsion was developed using Kodak D19 and Kodafix as per manufacturer instructions, and counterstained when desired with GIEMSA.

SMC microinjection. Exponentially growing SMCs on $100-\mathrm{mm}$ diameter tissue culture dishes were supplemented with $20 \mathrm{mM}$ Hepes $\mathrm{pH}$ 7.3 to maintain $\mathrm{pH}$ when exposed to open air. Grids, $\sim 4 \mathrm{~mm}^{2}$, were drawn on the side of the plates by hand with a 25 -gauge needle. Solutions for microinjection were adjusted to $100 \mathrm{mM} \mathrm{KCl}, 10 \mathrm{mM}$ sodium phosphate $\mathrm{pH}$ 7.3, and centrifuged to eliminate particulates. Solutions, in Eppendorf femtotip glass capillaries ( $1-\mu \mathrm{m}$ tip diameter $)$, were microinjected into all nuclei in a grid using a Narishige micromanipulator with constant flow under nitrogen pressure of $1.4 \mathrm{psi}$. The concentration of oligonucleotides used was either $200 \mathrm{ng} / \mu \mathrm{l}$ or $1 \mu \mathrm{g} / \mu \mathrm{l}$ oligonucleotide, to give an estimated 90,000 to 450,000 copies of the competitor in the cells, yielding comparable results. After microinjection, the culture was washed extensively with sterile PBS. After $15-16 \mathrm{~h}$, cells were pulsed for $8-10 \mathrm{~h}$ with $\left[{ }^{3} \mathrm{H}\right]$ thymidine and processed for autoradiography.

Photomicrography. Cells were photographed using a Nikon FM2 camera with technical pan film (ASA 25) using automatic exposure.

\section{Results}

$N F-\kappa B /$ Rel elements play a role in activation of the CMV immediate early promoter in SMCs. To determine whether the constitutive NF- $\kappa \mathrm{B} /$ Rel-like factor could activate transcription of the CMV ie promoter, transient transfection analysis was performed using CMV promoter-lac Z reporter constructs. As control, MoECAT, a CAT gene under the control of the Moloney Murine Leukemia Virus long terminal repeat, was co-transfected and extracts normalized for transfection efficiency. The full length CMV ie promoter-lacZ reporter construct ( $\mathrm{pON} 405$ ) was very active after transient transfection into SMCs compared to the pON407 construct, in which much of the promoter including all copies of the CMV NF- $\kappa$ B sites had been deleted (Fig. 1). This result contrasts with findings by Mocarski and co-workers with fibroblasts or T cells, in which these promoters gave comparable, low levels of activity and only the pON405 gave significant activity following induction of NF- $\kappa \mathrm{B}(5,6)$. The pON407.18R3 construct, in which three tandem copies of the CMV NF- $\kappa$ B sites were added to pON407, had more than tenfold higher activity than its parental construct. In contrast, pON407.18(TTT)R3, which has three copies of a mutated version of the NF- $\kappa \mathrm{B}$ site, exhibited levels indistinguishable from pON407. These data suggest that part of the activity of the CMV promoter is mediated through its NF- $\kappa \mathrm{B}$ sites. 


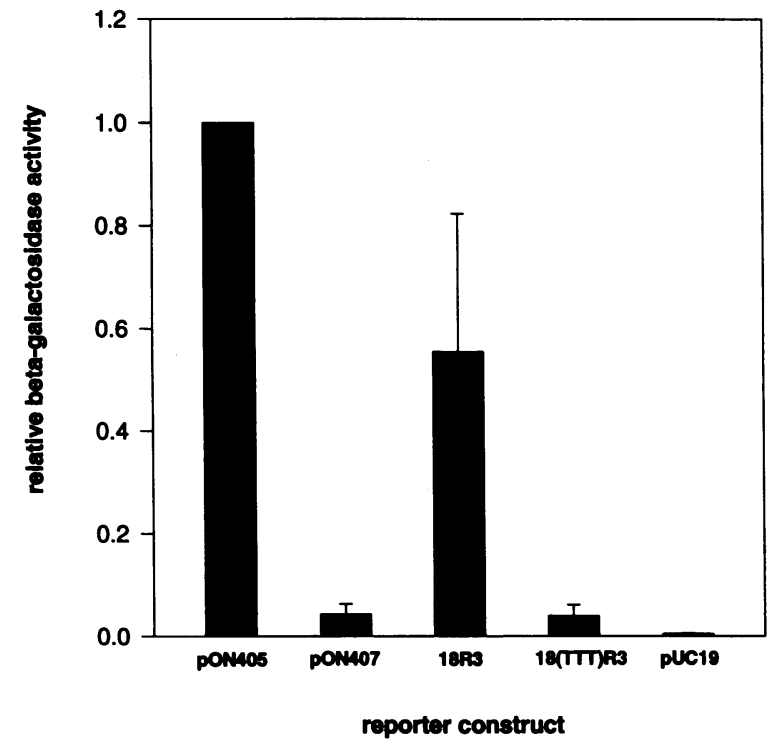

Figure 1. Activation of the CMV ie promoter in SMCs is partly mediated through its NF- $\kappa \mathrm{B}$ sites. CMV Lac $\mathrm{Z}$ reporter gene constructs were the following: pON405, 2000 bp of sequences upstream of the murine CMV iel transcription start site, including five full and six partial 18 bp NF- $\kappa$ B element repeats; pON407, a deletion of sequences up to -146 bp of the CMV iel transcription start in pON405, including all of the NF- $\kappa$ B elements; pON407.18R3, insertion of three tandem copies of the wild type NF- $\kappa$ B element 18R3 (CCTTAACGGGACTTTCCAA) just upstream of -146 bp of the pON407 (18R3); pON407.18(TTT)R3, insertion of three tandem copies of a mutated version of the NF- $\kappa$ B element termed 18T3 (CCTTAACTTTACTTTTCCAA) just upstream of -146 bp of the pON407(18(TTT)R3). pCMV-lac Z reporter constructs and control pUC19 DNA were cotransfected into SMCs with MoECAT DNA, as described in Methods. Lysates, normalized for transfection efficiency, were assayed for $\beta$-galactosidase activity (13). Results from experiments are given relative to the activity of the wild-type CMV-ie promoter construct pON 405 , arbitrarily set at 1.0 in each experiment. Shown are the means of seven separate experiments.

$N$-acetyl cysteine lowers basal $N F-\kappa B /$ Rel binding activity. To determine whether known inhibitors of NF- $\kappa \mathrm{B} /$ Rel induction might interfere with SMC-Rel activity, the antioxidant $N$ acetyl cysteine (NAC), which blocks activation of NF- $\kappa$ B/Rel binding (16), was used. Quiescent SMCs (which express levels of SMC-Rel indistinguishable from exponentially growing SMCs) were left untreated or were treated for $21.5 \mathrm{~h}$ with NAC. To test for inhibition of induction of NF- $\kappa$ B, some cell cultures were then administered IL- 1 or IL-6 for $1 \mathrm{~h}$, and nuclear extracts prepared. Electrophoretic mobility shift analysis was performed using a double-stranded (ds) oligonucleotide containing the NF$\kappa \mathrm{B}$ site upstream of the murine c-myc promoter (URE). Nuclear extracts from untreated SMCs yielded two bands in mobility shift analysis, as expected (Fig. 2). The bottom band contains p50 homodimers, which have been found unable to activate transcription in vivo $(1,3,4)$, and the upper band appears to represent a heterodimer of p50 and a second, as yet unidentified Rel subunit (9), designated SMC-Rel. NAC treatment significantly lowered the basal levels of binding activity to the URE. In contrast no decline was observed in binding to an AP-1 oligonucleotide used as a control for equal protein loading (data not shown). Both IL-1 and IL-6 induced NF- $\kappa$ B/Rel binding
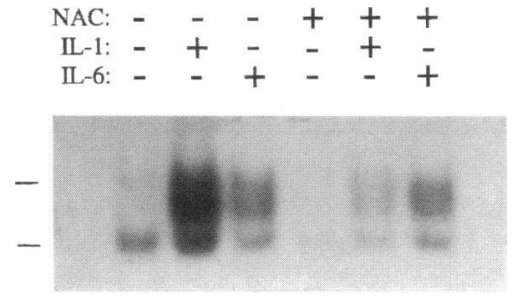

Figure 2. NAC downregulates basal SMC-Rel activity. Nuclear extracts, prepared from control (untreated) SMCs or from cultures pretreated with NAC at $20 \mathrm{mM}$ for $21.5 \mathrm{~h}$, then treated for one hour with

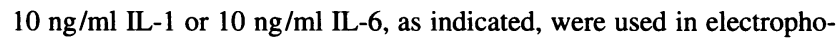
retic mobility shift analysis with the ds URE NF- $\kappa$ B oligonucleotide. The indicated upper and lower complexes represent: p50/SMC-Rel and p50 homodimer, respectively.

activity in SMCs. A major new band arises that has been found to supershift with antibodies specific for the p50 and p65 subunits (data not shown), and thus this band is likely to represent classical NF- $\kappa$ B (p50/p65) $(3,4)$. In addition, a slight increase was noted in p50/SMC-Rel binding. The levels of activity obtained after treatment with IL-1 were reduced by NAC. In contrast, the inducible level obtained by IL- 6 treatment was unaffected, suggesting perhaps that the mechanism of activation may not be sensitive to antioxidants. Thus NAC, an inhibitor of NF- $\kappa$ B activation, lowers levels of constitutive SMC NF$\kappa \mathrm{B} / \mathrm{Rel}$ factor binding.

$N A C$ inhibits $S M C N F-\kappa B /$ Rel functional activity. To test the effects of NAC on the functional activity of SMC NF- $\kappa$ B/ Rel, transient transfection assays were performed. SMCs, pretreated with NAC for $20 \mathrm{~h}$, were co-transfected with the CMV constructs, as above, and $\beta$-gal activity compared with untreated controls (Fig. 3). NAC treatment dramatically reduced the activity of the full length CMV ie promoter and the pON407.18R3 basal promoter driven by three wild-type NF- $\kappa$ B element con-

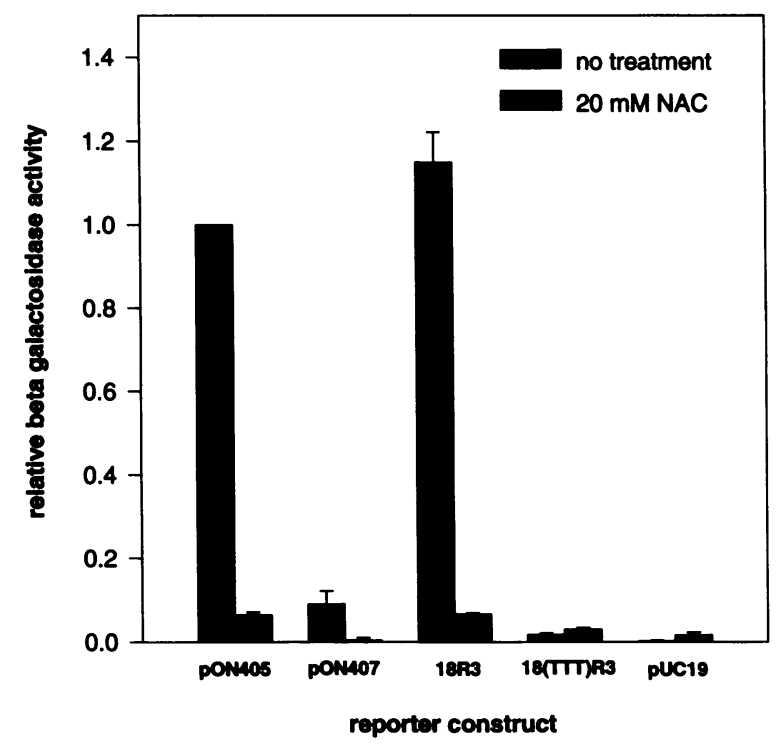

Figure 3. NAC inhibits transactivation through NF- $\kappa$ B elements. Cultures of SMCs were pretreated with NAC at 0 or $20 \mathrm{mM}$, then transfected with the CMV constructs, as described in the legend to Fig. 1. Lysates, normalized for transfection efficiency, were assayed for $\beta$-galactosidase activity. Results from experiments are given relative to the activity of the wild-type CMV-ie promoter construct pON 405 , arbitrarily set at 1.0. 
Table I. NAC and PTX Down-regulate NF- $\kappa B$ Activity in SMCs

\begin{tabular}{lccc}
\hline \multicolumn{1}{c}{ Treatment } & MoECAT & URE-TK-CAT & UREmut-TK-CAT \\
\hline None & $20.9 \pm 0.4^{*}$ & $9.6 \pm 0.3$ & $2.0 \pm 0.1$ \\
NAC $20 \mathrm{mM}$ & $24.6 \pm 1.4$ & $2.9 \pm 0.5$ & $1.9 \pm 0.1$ \\
PTX $2.5 \mathrm{mM}$ & $25.4 \pm 0.1$ & $4.0 \pm 0.2$ & $2.3 \pm 0.1$ \\
\hline
\end{tabular}

The indicated chloramphenicol transferase reporter constructs were transfected into untreated SMC or SMC pretreated with NAC or PTX at the indicated doses for $24 \mathrm{~h}$. Cells were transfected via electroporation with $30 \mu \mathrm{g}$ DNA at $300 \mathrm{~V}$ and $960 \mu \mathrm{F}$. After $24 \mathrm{~h}$ cells were harvested and assayed for CAT activity using a continuous fluor diffusion assay (13). Results are expressed as mean of two separate plates. ${ }^{*}$ Numbers represent cpm $\times 10^{-3}$ and are the mean of two separate plates.

struct, to that of the basal promoter in untreated cells, consistent with the drop in Rel factor binding activity.

We next monitored the effects of NAC and of pentoxifylline (PTX), another inhibitor of NF- $\kappa \mathrm{B} /$ Rel activation, on activity of NF- $\kappa \mathrm{B}$ element driven heterologous basal herpes simplex thymidine kinase (TK) promoter constructs. These CAT reporter gene constructs, driven by two copies of either the wild type URE, or mutant mURE1 (UREmut) that does not bind $\mathrm{NF}-\kappa \mathrm{B} / \mathrm{Rel}$ proteins, were transfected by electroporation into either untreated SMCs or following pretreatment with NAC or PTX for $24 \mathrm{~h}$. As control, MoECAT was similarly transfected. Table I demonstrates that URE-TK-CAT exhibited approximately five-fold higher activity than UREmut-TK-CAT in untreated cells, consistent with constitutive activity of SMC-Rel. Pretreatment of the cells with the agents NAC and PTX downregulated URE-TK-CAT, but not UREmut-TK-CAT or MoECAT, which is driven by other transcription factors. Thus NAC and PTX inhibit NF- $\kappa$ B-like activity in SMCs.

NAC and PTX inhibit SMC proliferation. In the course of above experiments, we noticed that SMC proliferation was slowed by addition of either NAC or PTX. To more carefully document these effects, exponentially growing SMCs were treated with various dosages of NAC or PTX and cell numbers determined after 24 or 48 h. Fig. 4 shows that both NAC and
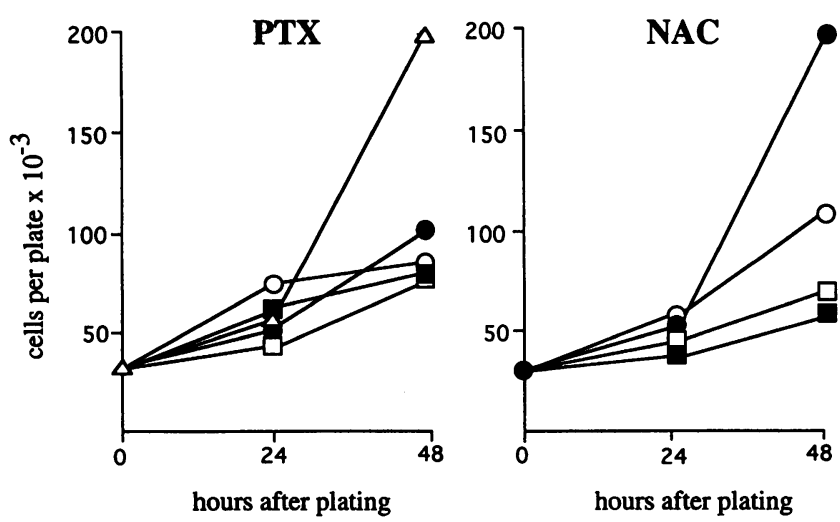

Figure 4. NAC and PTX inhibit SMC proliferation. At various times after treatment with NAC or PTX cells were trypsinized and counted by hemacytometer. Points plotted represent mean of three separate 35$\mathrm{mm}$ tissue culture dishes; standard deviations are all $<10 \%$ of the mean. PTX: $(\Delta) 0 \mathrm{mM}$; (O) $0.2 \mathrm{mM}$; (•) $0.5 \mathrm{mM}$; (匹) $1.0 \mathrm{mM}$; (口) $2.5 \mathrm{mM}$. NAC: (•) $0 \mathrm{mM}$; (O) $3 \mathrm{mM}$; () $10 \mathrm{mM}$; (匹) $30 \mathrm{mM}$.
Table II. NAC and PTX Do Not Affect Cell Viability

\begin{tabular}{llll}
\hline & & \multicolumn{2}{c}{ Hours after treatment } \\
\cline { 3 - 4 } & & 24 & 48 \\
\hline NAC (mM) & & & \\
& 3 & $92.7 *$ & 97.3 \\
& 10 & 91.3 & 97.1 \\
& 30 & 93.7 & 95.6 \\
PTX (mM) & & 92.1 & 93.7 \\
& 0 & & \\
& 0.2 & 92.7 & 97.3 \\
& 0.5 & 93.7 & 83.3 \\
& 1.0 & 96.7 & 96.3 \\
& 2.5 & 92.1 & 96.9 \\
& & 92.0 & 96.1
\end{tabular}

At the indicated times after treatment with NAC or PTX, cells were trypsinized and their viability determined by trypan blue exclusion. * Numbers represent the mean of two separate plates, with standard deviations $<5 \%$ of the mean.

PTX potently inhibited SMC growth in a dose-dependent fashion. Cultures treated with either $10 \mathrm{mM}$ NAC or $2.5 \mathrm{mM}$ PTX for $48 \mathrm{~h}$ were less than thirty percent the number of untreated cultures. The number of SMCs undergoing DNA synthesis was determined by labelling with $\left[{ }^{3} \mathrm{H}\right]$ thymidine and autoradiography. We used 12-h labeling windows at either 12-24 or 24$36 \mathrm{~h}$ after treatment. NAC and PTX both inhibited SMC DNA synthesis in a dose-dependent manner. For example, only $14.9 \%$ of cells underwent DNA synthesis 12-24 h after treatment with $10 \mathrm{mM}$ NAC compared with $85.9 \%$ for the control and only $7.7 \%$ did so $24-36 \mathrm{~h}$ after treatment compared with $69.8 \%$ seen with untreated cultures. SMC cultures incubated with $0,1.25$, 2.5 , or $5.0 \mathrm{mM}$ PTX gave percent labelled nuclei values of $69.8,45.3,38.8$, and $10 \%$, respectively, $24-36 \mathrm{~h}$ after treatment. These effects on SMCs are not due to toxicity, as trypan blue exclusion analysis demonstrates no decrease in viability at 24 or $48 \mathrm{~h}$ after treatment (Table II). SMCs maintained in these drugs for $5 \mathrm{~d}$ resumed growth when returned to normal medium (data not shown). In contrast, the inhibitory effects of $10 \mathrm{mM}$ NAC are not seen in vascular endothelial cells, which do not express a constitutive NF- $\kappa \mathrm{B} / \mathrm{Rel}$ activity (Fig. 5). Furthermore, vascular endothelial cells experienced no inhibition of DNA synthesis with NAC treatment at this dose (data not shown). Thus, NAC and PTX, two drugs which inhibit SMC $\mathrm{NF}-\kappa \mathrm{B} /$ Rel activity, inhibit SMC proliferation.

Microinjection of SMC with purified I $K B-\alpha$ inhibits SMC proliferation. To confirm a direct role of SMC NF- $\kappa$ B/Rel activity in proliferation, we microinjected SMCs with purified I $\kappa \mathrm{B}-\alpha$, a naturally occurring inhibitor of NF- $\kappa \mathrm{B}(7,8)$. Our previous experiments had shown that the binding of complexes containing the SMC-Rel factor was prevented by the presence of this inhibitor (9). Exponentially growing SMCs were microinjected with $\mathbf{I} \kappa \mathrm{B}-\boldsymbol{\alpha}$ or as control bovine serum albumin (BSA) at concentration of $1 \mu \mathrm{g} / \mu \mathrm{l}$. Assuming a microinjection volume of $10^{-11} \mathrm{ml}$ and a molecular weight of $37 \mathrm{kD}$ for this protein, we estimate that $\sim 150,000$ molecules of $I \kappa B-\alpha$ were introduced into the SMC. Cells were labelled for $8 \mathrm{~h}$ with $\left[{ }^{3} \mathrm{H}\right]-$ thymidine $16 \mathrm{~h}$ after microinjection, and processed for autoradiography. Table III shows that microinjection of I $\kappa$ B- $\alpha$ inhibited 


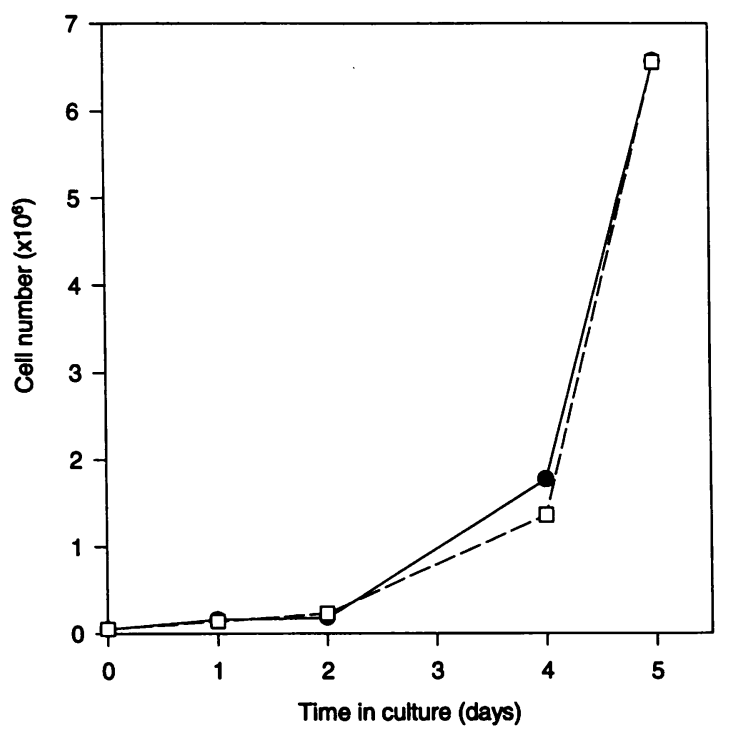

Figure 5. Endothelial cells proliferate in the presence of $10 \mathrm{mM}$ NAC Bovine aortic endothelial cells, incubated in the absence or presence of

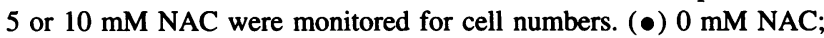
() $10 \mathrm{mM}$ NAC.

DNA synthesis. In contrast, microinjection of buffer alone or BSA does not inhibit DNA synthesis. Therefore the presence of the specific inhibitor of NF- $\kappa \mathrm{B} /$ Rel binding I $\kappa \mathrm{B}-\alpha$ appears to block SMC proliferation.

Microinjected $N F-\kappa B$ oligonucleotides inhibit SMC proliferation. As another measure of the specificity of inhibition of $\mathrm{NF}-\kappa \mathrm{B} / \mathrm{Rel}$ binding on SMC proliferation, oligonucleotides harboring wild-type and mutant NF- $\kappa \mathrm{B}$ sequences were microinjected into the SMCs. Recent data has demonstrated that microinjection of ds oligonucleotide harboring a transcription factor binding site can compete in vivo and inhibit the activity of the factor (18). SMCs were microinjected with ds wild-type $\mathrm{NF}-\kappa \mathrm{B}$ oligonucleotides from the c-myc gene (URE) or the kappa light chain gene $(\kappa \mathrm{B})$, which have both been shown to be functional within these cells (9). As controls for specificity for the effects, the series of four mutant URE oligonucleotides

Table III. Microinjection of I $\kappa$ B-alpha Inhibits SMC Proliferation

\begin{tabular}{lcc}
\hline Microinjected solution & Labeled nuclei/total cells & Percent labeled nuclei \\
\hline Experiment 1 & & \\
$\quad$ None & $89 / 173$ & 51.4 \\
Buffer & $102 / 213$ & 47.9 \\
BSA, $1 \mu \mathrm{g} / \mu \mathrm{l}$ & $63 / 119$ & 52.9 \\
$\mathrm{IkB}, 1 \mu \mathrm{g} / \mu \mathrm{l}$ & $26 / 141$ & 18.4 \\
Experiment 2 & & \\
None & $50 / 94$ & 53.1 \\
Buffer & $59 / 113$ & 52.2 \\
BSA, $1 \mu \mathrm{g} / \mu \mathrm{l}$ & $43 / 89$ & 48.3 \\
$\mathrm{IkB}, 1 \mu \mathrm{g} / \mu \mathrm{l}$ & $7 / 57$ & 12.3 \\
\hline
\end{tabular}

$16 \mathrm{~h}$ after microinjection with the indicated solution, cells were incubated in medium containing $\left[{ }^{3} \mathrm{H}\right]$ thymidine for $8 \mathrm{~h}$. Cells were then processed for autoradiography. Shown are two representative experiments.
Table IV. Microinjection of Double-stranded Oligonucleotides Harboring NF- $\mathrm{KB} / \mathrm{Rel}$ Wild-Type Sequences, but not Mutations That Ablate Binding, Inhibits SMC Proliferation

\begin{tabular}{lcc}
\hline Microinjected solution & Labeled nuclei/total cells & Percent labeled nuclei \\
\hline None & $119 / 167$ & 71.4 \\
mURE1 & $101 / 158$ & 63.9 \\
mURE2 & $116 / 175$ & 66.3 \\
mURE3 & $107 / 147$ & 72.8 \\
mURE4 & $35 / 136$ & 25.7 \\
URE & $19 / 109$ & 17.7 \\
$\kappa B$ & $39 / 137$ & 29.0 \\
\hline
\end{tabular}

$16 \mathrm{~h}$ after microinjection with $200 \mathrm{ng} / \mu \mathrm{l}$ of the indicated oligonucleotide, cells were incubated in medium containing $\left[{ }^{3} \mathrm{H}\right]$ thymidine for $10 \mathrm{~h}$ and subjected to autoradiography, as above.

used in our original binding study (9) (see Methods for sequences) were similarly microinjected; these include three oligonucleotides with mutations within the core binding region (mURE1, mURE2, and mURE3) such that binding is significantly ablated and one outside of the core region that continues to bind NF- $\kappa$ B/Rel complexes (mURE4) (9). For each oligonucleotide, a grid was marked within a field and all cells microinjected. After $16 \mathrm{~h}$, cells were labelled with $\left[{ }^{3} \mathrm{H}\right]$ thymidine for $10 \mathrm{~h}$ and analysed for percent labeled nuclei, as above. Furthermore, after $24 \mathrm{~h}$ cells were photographed to compare cell density. As can be seen in Table IV, microinjection of wild type or mutant NF- $\kappa$ B elements that can bind NF- $\kappa \mathrm{B} / \mathrm{Rel}$ factors, i.e., URE, $\kappa \mathrm{B}$ or the mURE4, significantly inhibited the number of cells undergoing DNA synthesis. In contrast, oligonucleotides with mutations that prevent Rel factor binding (mURE1 to 3) had little affect on SMC entry into S phase. As expected, injection with buffer alone exerted no effect (none, Table IV). Consistent with this finding, we observed that $24 \mathrm{~h}$ after microinjection, SMC density in the grid microinjected with oligonucleotides harboring elements that bind NF- $\kappa \mathrm{B} / \mathrm{Rel}$ was significantly less than following microinjection with those with mutations that ablate binding. Fig. 6 illustrates the results obtained with the URE vs mURE1; similar results were obtained with other elements that bind NF- $\kappa \mathrm{B} / \mathrm{Rel}$ vs the non-binding mutations (data not shown). Therefore ds oligonucleotides that bind NF- $\kappa \mathrm{B} /$ Rel complexes can selectively inhibit SMC proliferation presumably by competing in vivo for SMC NF- $\kappa \mathrm{B} / \mathrm{Rel}$ binding.

\section{Discussion}

Here we demonstrate that the previously identified constitutive $\mathrm{NF}-\kappa \mathrm{B} /$ Rel-like activity (containing SMC-Rel) is essential for proliferation of bovine aortic SMCs in culture. NAC and PTX, which reduce SMC NF- $\kappa$ B/Rel activity, inhibit SMC proliferation. Furthermore, microinjection of specific inhibitors of SMCRel, including I $\kappa \mathrm{B}-\alpha$ and ds oligonucleotides containing NF$\kappa \mathrm{B} / \mathrm{Rel}$ binding sites, similarly reduce the rate of SMC proliferation. Thus growth of SMCs is directly inhibited upon reduction in SMC NF- $\kappa$ B/Rel activity. Furthermore, transfection analysis indicated that the constitutive SMC NF- $\kappa \mathrm{B} /$ Rel activity plays a role in transactivation of the $\mathrm{CMV}$ ie promoter. Thus the promoter containing multiple NF- $\kappa \mathrm{B}$ elements was active with- 


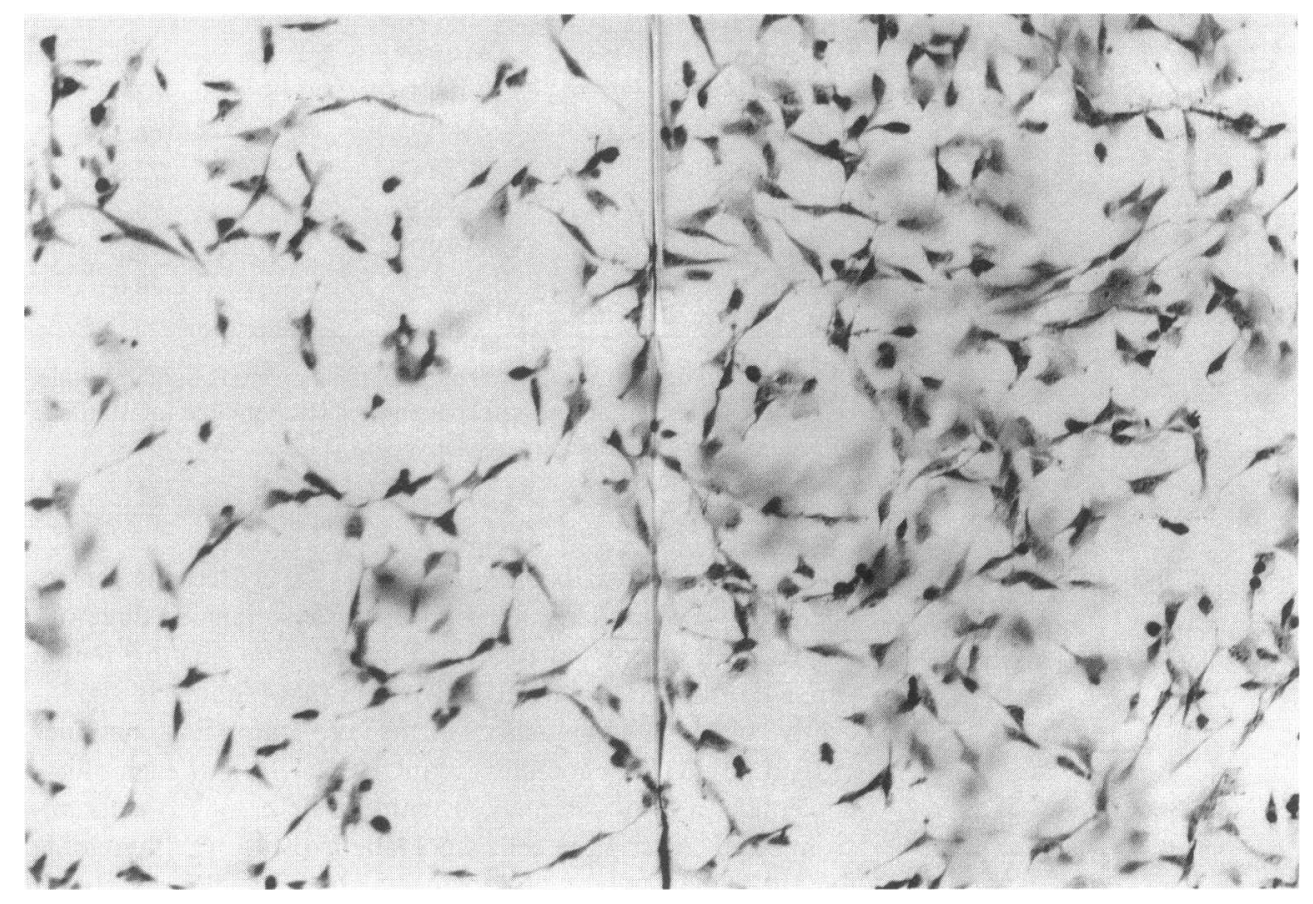

Figure 6. Microinjection of double-stranded oligonucleotides harboring functional NF- $\kappa$ B binding sites inhibit SMC growth. All the SMCs within a grid were microinjected with $1 \mu \mathrm{g} / \mu \mathrm{l}$ of either URE or mURE1 ds oligonucleotides. After $24 \mathrm{~h}$, cells were fixed in $-20^{\circ} \mathrm{C}$ methanol, air dried and photographed $(100 \times)$ using technical pan film, ASA 25. Comparable inhibition was obtained with $200 \mathrm{ng} / \mathrm{ml}$ oligonucleotide, and with the other oligonucleotides harboring elements that bind NF$\kappa \mathrm{B} /$ Rel factors, described in Table IV (data not shown). out additional activation of NF- $\kappa \mathrm{B} /$ Rel and partial activity of the truncated version of this promoter was restored upon introduction of wild-type but not mutant copies of the CMV NF- $\kappa$ B sites. In contrast, the wild-type CMV ie promoter was previously shown to be only active in $\mathrm{T}$ cells after induction of $\mathrm{NF}-\kappa \mathrm{B} /$ Rel activity. The discovery of an activity that is necessary for vascular smooth muscle proliferation provides a potential new therapeutic target with important implications for cardiovascular research.

Because proliferation of SM cells within the intimal layer of arterioles is thought to play a major role in the progression of atherosclerosis and restenosis, there is tremendous interest in identifying ways of inhibiting SMC growth. Importantly, the subcultured SMC used here resemble neointimal SMC in that they are in the synthetic rather than the contractile state. We and others have demonstrated that antisense c-myb oligonucleotides inhibit SMC growth (19-21); similar antisense technologies targetting the SMC-Rel factor in the region of angioplasty might be predicted to inhibit SMC proliferation and restenosis. However, this approach has proven difficult to develop for in vivo use. Our finding that agents such as NAC and PTX, which are currently in clinical use for other purposes, inhibit vascular SMC proliferation might permit an easier, pharmacologic approach for the treatment of atherosclerosis, restenosis, and other diseases involving hyperproliferation of SMCs. Other antioxidants, which have been found to inhibit activity (4) may also be effective. Of note, we have recently demonstrated that human uterine SMCs, including both normal human myometrium and uterine leiomyoma (fibroids) express constitutive NF- $\kappa$ B-like activity (R. Bellas, R. Weiss, and G. Sonenshein, manuscript in preparation).

It has been shown that the antioxidants probucol and butyl- ated hydroxytoluene are effective in reducing plaque formation in animal models of atherosclerosis (22-27). It has been suggested these drugs have been successful because of their ability to lower oxidized-LDL levels. However, our findings raise the possibility that these drugs may also affect SMC NF- $\kappa$ B/Rel activity and thus directly inhibit SMC proliferation. Furthermore, recent evidence has leant strong support to a longstanding notion that atherosclerosis and CMV infection may be associated (reviewed in reference 28 ). In a large percentage of restenosis lesions from patients, CMV infection correlated with inactivation of the tumor suppressor p53 (11), thereby subverting normal SMC growth control. We have found that the CMV ie promoter is activated by the NF- $\kappa$ B-like activity in SMCs. Thus therapies targetting the SMC-Rel factor may be able to elicit two very different benefits: interference with CMV replication, and direct inhibition of SMC growth.

\section{Acknowledgments}

The authors gratefully acknowledge U. Siebenlist, J. Sipe, E. Mocarski, and D. Larson for providing purified I $\kappa$ B- $\alpha$-GST, IL-1 and IL-6, CMVlac $\mathrm{Z}$ constructs, and endothelial cells, respectively. The authors also thank Frank Solomon for kindly allowing us access to his microinjection equipment. This work was supported by Public Health Service grants HL 13262 and CA 36355.

\section{References}

1. La Rosa, F., J. Pierce, and G. E. Sonenshein. 1993. Differential regulation of the c-myc oncogene promoter by the NF- $\kappa \mathrm{B} /$ Rel family of transcription factors. Mol. Cell. Biol. 14:1039-1045.

2. Ji, L., M. Arcinas, and L. Boxer. 1994. NF- $\kappa$ B sites function as positive 
regulators of expression of the translocated c-myc allele in Burkitt's lymphoma. Mol. Cell. Biol. 14:7967-7977.

3. Grilli, M., J. J.-S. Chiu, and M. J. Lenardo. 1993. NF- $\kappa$ B and Rel: participants in a multiform transcriptional regulatory system. Int. Rev. Cytol. 143:1-62.

4. Baeuerle, P. 1991. The inducible transcription factor NF- $\kappa$ B: regulation by distinct protein subunits. Bioch. Biophys. Acta. 1072:63-80.

5. Sambucetti, L. C., J. M. Cherrington, G. W. G. Wilkinson, and E. S. Mocarski. 1989. NF- $\kappa$ B activation of the cytomegalovirus enhancer is mediated by a viral transactivator and by T cell stimulation. EMBO (Eur. Mol. Biol. Organ.) J. 13:4251-4258.

6. Cherrington, J. M., and E. Mocarski. 1989. Human cytomegalovirus transactivates the alpha promoter-enhancer via an 18-base pair repeat element. J. Virol. 25:1435-1440.

7. Baeuerle, P. A., and D. Baltimore. 1988. IkB: a specific inhibitor of the NF- $\kappa$ B transcription factor. Science (Wash. DC). 242:540-546.

8. Baeuerle, P. A and D. Baltimore 1989. A $65 \mathrm{kD}$ subunit of active NF$\kappa \mathrm{B}$ is required for inhibition of NFkB by IkB. Genes Dev. 3:1689-1698.

9. Lawrence, R., L. J. Chang, U. Siebenlist, P. Bressler, and G. E. Sonenshein. 1994. Vascular smooth muscle cells express a constitutive NF- $\kappa$ B-like activity. J. Biol. Chem. 269:28913-28918.

10. Ross, R. 1993. Pathogenesis of atherosclerosis: a perspective for the 1990s. Nature (Lond.). 362:801-808.

11. Speir, E., R. Modali, E.-S. Huang, M. B. Leon, F. Shawl, T. Finkel, and S. E. Epstein. 1994. Potential role of human cytomegalovirus and p53 interaction in coronary restenosis. Science (Wash. DC). 265:391-394.

12. Chen, C., and H. Okayama. 1987. Calcium phosphate mediated gene transfer. Mol. Cell Biol. 7:2745-2755.

13. Neumann, J. R., C. A. Morency, and K. O. Russian. 1987. A novel rapid assay for chloramphenicol acetyl transferase gene expression. Biotechniques. 5:444-446.

14. Hall, C. V., P. E. Jacob, G. M. Ringold, and F. Lee. 1983. Expression and regulation of escherichia coli lacZ gene fusions in mammalian cells. J. Mol. Appl. Genet. 2:101-108.

15. Bellas, R. E., N. Hopkins, and Y. Li. 1993. The NFkB binding site is required for efficient replication of simian immunodeficiency virus of macaques in macrophages in vitro. J. Virol. 67:4334-4339.

16. Staal, F. J. T., M. Roederer, L. A. Herzenberg, and L. A. Herzenberg 1990. Intracellular thiols regulate activation of nuclear factor $\mathrm{kB}$ and transcription of human immunodeficiency virus. Proc. Natl. Acad. Sci. USA. 87:9943-9947.
17. Biswas, D. K., B. J. Dexube, C. M. Ahlers, and A. B. Pardee. 1993. Pentoxifylline inhibits HIV-1 LTR driven gene expression by blocking NF-kB action. J. Acq. Immun. Def. Syn. 6:778-786.

18. Lamb, N. J., A. Fernandez, N. Tourkine, P. Jeanteur, and J. M. Blanchard. 1990. Demonstration in living cells of an intragenic negative regulatory element within the rodent c-fos gene. Cell. 61:485-496.

19. Brown, K. E., M. S. Kindy, and G. E. Sonenshein. 1992. Expression of the c-myb proto-oncogene in bovine vascular smooth muscle cells. J. Biol. Chem. 267:4625-4630.

20. Simons, M., and R. D. Rosenberg. 1992. Antisense nonmuscle myosin heavy chain and c-myb oligonucleotides suppress smooth muscle cell proliferation in vitro. Circ. Res. 70:835-843.

21. Simons, M., E. R. Edelman, J. L. DeKeyser, R. Langer, and R. D. Rosenberg. 1992. Antisense c-myb oligonucleotides inhibit intimal arterial smooth muscle cell accumulation in vivo. Nature (Lond.). 359:67-70.

22. Schneider, J. E., B. C. Berk, M. B. Gravanis, E. C. Santoian, G. D. Cipolla N. Tarazona, B. Lassegue, and S. B. King. 1993. Probucol decreases neotintima formation in a swine model of coronary artery balloon injury. A possible role for antioxidants in restenosis. Circulation. 88:628-637.

23. Carew, T. E., D. C. Schwenke, and D. Steinberg. 1987. Antiatherogenic effect of probucol unrelated to its hypocholesterolemic effect. Proc. Natl. Acad. Sci. USA. 84:7725-7729.

24. Kita, T., Y. Nagano, M. Yokode, K. Ishii, N. Kume, A. Ooshima, H. Yashide, and C. Kawai. 1987. Probucol prevents the progression of atherosclerosis in Watanabe heritable rabbit, an animal model for familial hypercholesterolemia. Proc. Natl. Acad. Sci. USA. 84:5928-5931.

25. Ferns, G. A. A., L. Forster, A. S. Lee, M. Konneh, J. N. Zadeh, and E. E. Anggard. 1992. Probucol inhibits neointimal thickening and macrophage accumulation after balloon injury in the cholesterol-fed rabbit. Proc. Natl. Acad. Sci. USA. 89:11312-11316.

26. Freyschuss, A., A. S. Rahm, J. Swedenborg, P. Henrikson, I. Bjorkhem, and J. Nilsson. 1993. Antioxidant treatment inhibits the development of intimal thickening after balloon injury of the aorta in hypercholesterolemic rabbits. $J$. Clin. Invest. 91:1282-1288.

27. Bjorkhem, I., A. H. Freyschuss, O. Breuer, U. Diczfalusy, L. Berglund, and P. Henriksson. 1991. The antioxidant butylated hydroxytoluene protects against atherosclerosis. Arter. Thromb. 11:15-22.

28. Melnick, J. L., E. Adam, and M. E. Debakey. 1993. Cytomegalovirus and atherosclerosis. Eur. Heart. J. 14:K30-38. 